Sains Malaysiana 49(3)(2020): 517-525

http://dx.doi.org/10.17576/jsm-2020-4903-06

\title{
Exploring the Molecular Interactions between Neoculin and the Human Sweet Taste Receptors through Computational Approaches
}

(Meneroka Interaksi Molekul antara Neokulin dan Reseptor Rasa Manis Manusia melalui Pendekatan Pengiraan)

\author{
RAGHEED HUSSAM YOUSIF, HABIBAH A. WAHAB, KAMYAR SHAMELI \& NURUL BAHIYAH AHMAD KHAIRUDIN*
}

\section{ABSTRACT}

Neoculin is a sweet taste protein capable of modifying sour taste into sweet taste. Neoculin, along with other sweeteners, are received by the human sweet taste receptors TIR 2 and TIR3. To date, there has been few studies regarding how neoculin interacts with the human sweet taste receptors in molecular level. In this study, computational approaches were applied to elucidate how neoculin interact with T1R2 and T1R3 at molecular level. In order to achieve this research, homology modeling for T1R2 and T1R3 was performed to predict their structure. A protein-protein docking study was conducted between neoculin and T1R2 and T1R3, which displayed a strong relationship with the previous experimental findings regarding the important residues of neoculin, and how they interact with the ATD domain of T1R3. These residues are His11, Asp91, Tyr21, Asn44, Arg48, Tyr 65, Val72, and Phe94. The best docked complexes were then subjected to molecular dynamics simulation for further analysis. The molecular dynamics simulation results showed the contributions of the important residues of neoculin in forming hydrogen bonds with the residues of the receptors. The binding energy between neoculin and each of T1R2 and T1R3 were also calculated. These results concluded that neoculin sweet taste and taste modifying abilities are only active when it binds to the amino terminal domain of T1R3.

Keywords: Homology modeling; molecular dynamics simulation; neoculin; protein-protein docking; T1R2।T1R3

\section{ABSTRAK}

Neokulin adalah protein rasa manis yang mampu mengubah rasa masam menjadi rasa manis. Neokulin, seperti pemanis lain, diterima oleh reseptor perasa manis manusia iaitu T1R2 dan T1R3. Sehingga kini, sudah terdapat beberapa kajian yang dijalankan untuk mengenal pasti bagaimana neokulin berinteraksi dengan reseptor kemanisan pada peringkat molekul. Dalam kajian ini, kaedah pengiraan digunakan untuk memperjelaskan bagaimana neokulin berinteraksi dengan T1R2 dan T1R3 pada tahap molekul. Bagi menjalankan kajian ini, permodelan homologi untuk T1R2 dan T1R3 telah dijalankan untuk menjangkakan struktur tersebut. Kajian pendokkan protein-protein telah dijalankan antara neokulin dan T1R2 serta T1R3, yang menunjukkan terdapat hubungan yang kuat dengan penemuan kajian sebelumnya mengenai sisa penting neokulin dan bagaimana ia berinteraksi bersama domain ATD kepada T1R3. Sisa tersebut adalah His11, Asp91, Tyr21, Asn44, Arg48, Tyr 65, Val72 dan Phe94. Kompleks dok terbaik itu kemudiannya diuji kepada simulasi dinamik molekul untuk analisis lanjutan. Hasil simulasi dinamik molekul menunjukkan sumbangan daripada sisa penting neokulin dalam membentuk ikatan hidrogen dengan sisa reseptor. Tenaga yang mengikat antara Neokulin dan setiap T1R2 dan T1R3 juga turut dihitung. Keputusan ini menyimpulkan bahawa rasa manis neokulin dan kebolehan mengubah suai adalah aktif hanya apabila ia mengikat kepada domain terminal amino T1R3.

Kata kunci: Neokulin; pemodelan homologi; pendokkan protein-protein; simulasi molekul dinamik; T1R2।T1R3

\section{INTRODUCTION}

Previous studies reported that some types of proteins which isolated from several kinds of tropical fruits has a sweet taste including monellin, thaumatin, brazzein, and mabinlin. Likewise, other studies reported other types of proteins capable of modifying sour taste into sweet taste, but they are not naturally sweet including miraculin.

However, a sweet protein by the name of neoculin is the only identified protein as a taste modifier and sweet by itself (Kurimoto et al. 2007; Masuda \& Kitabatake 2006). Neoculin is a heterodimeric protein consists of $\mathrm{N}$-glycosylated acidic subunit (NAS) which is including
113 residues, and basic subunit (NBS). It was successfully in purifying and characterizing by Yamashita et al. (1990) using sodium chloride from the pulp of Curculigo latifolia, and crystalized by Shimizu-Ibuka et al. (2006) using X-Ray diffraction at $2.76 \mathrm{~A}^{\circ}$ resolution. Sweet proteins and other types of sweeteners including artificial sweet materials, sugar, and amino acids are capable of binding with the human sweet taste receptors T1R2 and T1R3. They belong to class $\mathrm{C}$ of the G-protein coupled receptors (GPCR). T1R2 and T1R3 are members of the T1R family (Ohta et al. 2011). Commonly, the mutual structure of the class $C$ GPCR has a large amino terminal domain (ATD) containing 
a venus flytrap domain (VFD) and cysteine rich domain (CRD). CRD is connecting the ATD to the transmembrane domain (TMD) (Maillet et al. 2015). In addition to that, GPCR as the biggest member of the membrane proteins, they play a key role for signal transportation across the entire cell membrane, and they act as important drug targets. In the past several years, the computational 3D structure of GPCR have become a significant for drug discovery researches, especially when they help as extra templates for homology modelling studies (Castleman et al. 2018; Loo et al. 2018; Yarnitzky et al. 2010).

Homology modeling studies were reported on each domain of T1R2 and T1R3 separately by Cui et al. (2006) in order to understand the heterodimeric nature of the human sweet taste receptors. In addition, similar homology modeling was accomplished by Assadi-Porter et al. (2010) on the VFD domain combined only associated with experimental studies, to understand the sweet taste enhancers, and other work by Masuda et al. (2012) to investigate the binding modes between the low molecular weight sweeteners with T1R2 and T1R3. A complete homology modelling work was performed by Shrivastav and Srivastava (2013) using multiple protein structure prediction tools including ITASSER, SWISS MODEL, and PRIME. Comparable researches were reported to determine the anatomy of mammalian T1R2 and T1R3 (Cheron et al. 2017), and to study the interactions of GPCR with different ligands (Kim et al. 2017).

One of the homology modeling applications is molecular docking (Oshiro et al. 2004). It is a computational method use to predict the conformation of a receptor-ligand complex. The ligand can be small molecule or protein, and the receptor can be either nucleotide or other protein (Altschul et al. 1997; Dias \& de Azevedo Jr. 2008). The protein-protein docking method is an essential approach to deliver extra data regarding the protein-protein interactions (PPI) (Huang 2015). A computational work had been carried out to provide more insight into the interactions between the human sweet taste receptors with sweet ligands including brazzin, aspartame, neotame, and cyclamate as multi ligand receptors (Cui et al. 2006). Besides the computational work, previous experimental work reported that neoculin is only received by the ATD of T1R3 (Koizumi et al. 2007), and to explain the effect of $\mathrm{pH}$ on the agonism and antagonism activities between neoculin and the human sweet taste receptors (Nakajima et al. 2008), which is influenced mainly by the His11 of neoculin as a pH sensor (Nakajima et al. 2011). Moreover, a work by Koizumi et al. (2015) showed that Arg48, Tyr65, Val72, and Phe94 are the key residues of neoculin which are responsible for the binding and the activation of T1R2 and T1R3.

Exploring the conformational space for the ligandreceptor complexes is one of the applications of the molecular dynamics (MD) simulation in biomolecular studies. A previous MD simulation research was reported on neoculin which claimed that $\mathrm{H} 11$ of neoculin played a key role for the sweetness of neoculin as a dimer with
Asp91, beside another dimer of His14 and Tyr21. In addition to that, the same study informed that Asn44 of neoculin NBS is an important residue that might involve in the interactions with the sweet taste receptors (Ohkubo et al. 2015).

To date, the structure activity relationship of the sweet protein neoculin and the human sweet taste receptors is not comprehensively investigated. The binding activity of neoculin towards T1R2 and T1R3 can only be understood by looking at the structural features of both proteins (Koizumi et al. 2015, 2007). In this paper, a complete homology modeling study was carried out on the entire structure of T1R2 and T1R3, in order to provide a 3D structure for each receptor. A protein-protein docking was conducted between chain B of neoculin and T1R2 and T1R3, to provide more insights regarding how neoculin interacts with T1R2 and T1R3. Finally, molecular dynamics (MD) simulation study was carried out on the best docked complexes. The current results unleashed more details on the nature of the molecular interactions between neoculin and the sweet taste receptors by explaining and connecting the previous experimental findings and adding new results based on those findings.

\section{Materials AND Methods}

The homology modeling study included a Basic Local Alignment Tool (BLAST) (Altschul et al. 1997) and hidden Markov models (HMM-HMM) alignment search was employed to search for the potential protein templates from the protein data bank (PDB) database. The sequence alignment between the templates sequences (PDBID 2E4U and 4OR2) and the target protein was performed using Clustal Omega (Sievers et al. 2011). The 3D models of T1R2-T1R3 and the loop modeling were built using MODELLER 9.16 (Eswar et al. 2007). MODELLER produced 100 models for each protein, and the models with the lowest energy value were chosen. The secondary structure of the loop segments was predicted using Jpread (Cuff et al. 1998). The quality of the produced models were checked using Ramachandran plot (Ho \& Brasseur 2005). Several tools including CASTp (Binkowski et al. 2003) BSpred (Mukherjee \& Zhang 2011), and COACH (Yang et al. 2013) were selected to predict the neoculin binding sites. The protein-protein docking simulation was carried out using ClusPro which is based on PIPER approach (Comeau et al. 2004; Kozakov et al. 2017) and PATCHDOCK (Schneidman-Duhovny et al. 2005). DIMPLOT (Wallace et al. 1995) was employed to analyses the protein-protein complex. The protein complexes were inserted into a 1-palmitoyl-oleoyl-sn-glycero-3phosphocholine (POPC) lipid bilayer. The complexes orientation into the membrane were determined using Orientation of Proteins in Membrane (OPM) (Lomize et al. 2012). The membrane system of each complex was set up using a graphical user interface for CHARMM (CHARMM-GUI) (Lee et al. 2015). CHARMM-GUI generated an input to Groningen Machine for Chemical 
Simulations (GROMACS) molecular package after the membrane system preparation. GROMACS was used to perform the energy minimization, temperature and pressure equilibration, and $10 \mathrm{~ns}$ of MD production. The hydrogen bond occupancy was calculated using readHBmaps. The binding energy was calculated using g_MMPBSA(Kumari et al. 2014).

GROMACS was used to carried out the energy minimization to relax the system from any geometric clashes. A 500 steps of energy minimization were carried out for each system based on steepest decent algorithm. After the minimization step, the membrane systems were subjected to two phases equilibration processes. The first process was a short NVT (the constant number of particles, volume and temperature) which then followed by longer NPT (the constant number of particles, pressure and temperature) as the second equilibration process. A 100ps of NVT was carried out to equilibrate the temperature of the entire membrane complex system, by using V-rescale temperature coupling, and $1 \mathrm{~ns}$ of NPT equilibration for the system complexes using Berendsen coupling. During the equilibration process, the system was allowed to equilibrate at a $303.15 \mathrm{~K}$ temperature and 1 bar pressure.

After completing the equilibration stage, $10 \mathrm{~ns}$ of MD production was subjected to the membrane complexes. The hydrogen bond occupancy was calculated using readHBmaps. The binding energy was calculated using molecular mechanics Poisson Boltzmann surface area (MMPBSA) method by using g_mmpbsa tool. g_mmpbsa calculated the binding energy of the first and the last 100 frames of the xtc file. The tool gmx filter used to extract one frame in every 50 frames in xtc file, in order to produce a total of 100 frames for calculating the overall binding energy. The tool readHBmap was used to calculate the hydrogen bond occupancy.

\section{RESULTS AND DISCUSSION}

\section{HOMOLOGY MODELING}

Results from BLAST and HMM-HMM alignment tools showed that the protein data bank (PDBID: 2E4U) and (PDBID: 4OR2) are the closest template which covered most of the primary sequence of T1R2 and T1R3. Each of the templates $2 \mathrm{E} 4 \mathrm{U}$ and $4 \mathrm{OR} 2$ belongs to the class $\mathrm{C}$ of GPCR, and they include the domains ATD, CRD and TMD, which are similar to the structure of T1R2 and T1R3. In addition to that, each template was crystalized with acceptable resolution, thus they provided templates that are more accurate for T1R2 and T1R3. Ramachandran plot analysis of the templates T1R2 and T1R3 showed $81.6 \%$ and $84.2 \%$ of the residues located in the most favoured regions for T1R2 and T1R3. Figure 1(a) shows the 3D models of T1R2 and T1R3 were found to include loop structure at the terminal of each model, which occur due to the low sequence identity at the loop region between the target and the template sequences. Thus, the secondary structures of each loop were predicted using Jpred tool, and the loop modeling was re-constructed as shown in Figure 1(b). The current modeling process used several tools to produce the multi domain structure of T1R2 and T1R3, which are unlike the models from that of Shrivastav and Srivastava (2013), for their developed models used completely automated methods including ITASSER, SWISS MODEL, and PRIME.

\section{PROTEIN-PROTEIN DOCKING}

The docking study between neoculin and T1R2 and T1R3 produced several complexes. The best docking complexes as presented in Table 1 were selected according to two standards. The first standard was grounded on previous experimental studies by Koizumi et al. $(2015,2007)$ which indicated that NBS of neoculin binds to the ATD of T1R3, specifically by the residues Arg48, Tyr65, Val72, and Phe94. The second standard to select the best complexes, was based on the number of the important residues, that were predicted as the binding site residues using CastP and $\mathrm{COACH}$. These residues were found to appear frequently in the docking simulation as shown in Table 1. The complexes were T1R3PATCH2, T1R3PIPER4, and T1R3PIPER5. These results were compared with the same docking results produced between neoculin and T1R2 to study the difference in the binding of neoculin towards T1R2 and T1R3. The results of these comparisons are explained in the following paragraphs.

The previous findings of Nakajima et al. (2011) showed that His 11 was a critical $\mathrm{pH}$ sensor to activate the neoculin taste modification ability, and His 11 did not bind directly to the sweet taste receptors, but it influences the sweetness of neoculin. Additional work by Ohkubo et al. (2015) showed that His11 and Asp91 are interfaced as a dimer in neoculin to play a significant role on the sweetness of neoculin, followed by the dimer of His 14 and Tyr 21 . Moreover, the same study indicated that Asn44 is an important residue at the receptor activation region of the neoculin NBS. The current docking findings are related to the previous work of Nakajima et al. (2011) for it showed that His11 did not bind to the human sweet taste receptors at all, and it was not predicted as a binding site either. The current findings are linked to the study of Ohkubo et al. (2015) for Tyr21 and Asp91 were predicted as binding residues and form hydrogen bonds in T1R3PIPER3, T1R3PIPER5, T1R3PATCH1, T1R3PATCH2 as shown in Table 1. Figure 2(a) shows the hydrogen bond interaction between Asp91 and T1R3, and Figure 2(b) shows the interaction between Tyr21 and T1R3. The same case is similar for residue Asn44, as the current results shows that it is predicted as a binding residue and it binds to T1R3 in T1R3PIPER4, T1R3PIPER5 and T1R3PATCH5 complexes as presented in Table 1. Figure 2(c) and Figure 2(d) shows how Asn44 binds to T1R3. The work by Koizumi et al. (2015) showed that the residues Arg48, Tyr65, Val72 and, Phe94 determine the affinity of neoculin with the human sweet taste receptors regardless of the $\mathrm{pH}$. The current findings show that only the residues Tyr65 and Phe94 were 


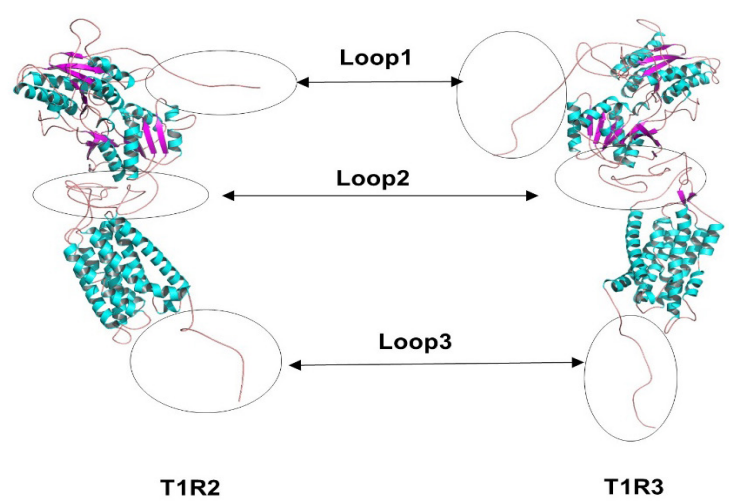

(a)

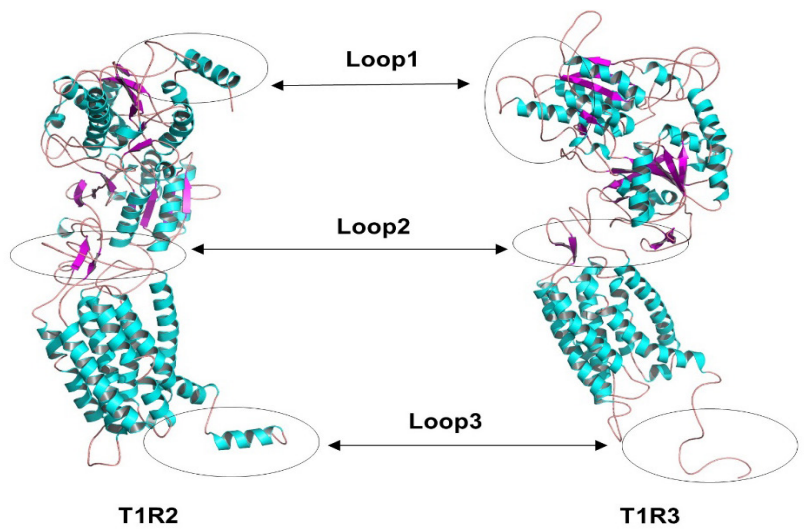

(b)

FIGURE 1. The 3D models of T1R2 and T1R3. (a) The 3D models of T1R2 and T1R3 before the loop modeling. (b) The 3D models of T1R2 and T1R3 after the loop modeling

TABLE 1. The docking results between T1R3 and neoculin chain B. The underline residues formed hydrogen bonds to the receptors in more than one complex, and the residues in bold were predicted as binding residues

\begin{tabular}{llllllllllll}
\hline Method & Model Number & \multicolumn{10}{c}{ Neoculin Residue } \\
\hline PIPER DOCK & T1R3PIPER1 & $\underline{\mathbf{3 6}}$ & $\underline{90}$ & $\mathbf{8 9}$ & $\underline{\mathbf{9 3}}$ & $\underline{2}$ & $\underline{1}$ & & \\
& T1R3PIPER2 & $\underline{90}$ & 17 & $\underline{\mathbf{3 6}}$ & $\underline{\mathbf{3 8}}$ & & & & \\
& T1R3PIPER3 & $\underline{93}$ & $\mathbf{7 7}$ & $\mathbf{3 7}$ & $\underline{\mathbf{3 6}}$ & $\underline{\mathbf{3 5}}$ & $\underline{\mathbf{2 1}}$ & $\underline{\mathbf{9 1}}$ & $\underline{\mathbf{3 8}}$ & $\underline{\mathbf{2}}$ \\
& T1R3PIPER4 & $\underline{38}$ & $\underline{34}$ & $\mathbf{2 6}$ & $\mathbf{2 8}$ & $\underline{\mathbf{3 6}}$ & $\underline{\mathbf{4 4}}$ & $\underline{90}$ & $\underline{1}$ & $\underline{\mathbf{3 6}}$ \\
& T1R3PIPER5 & $\mathbf{7 3}$ & $\underline{\mathbf{4 4}}$ & $\mathbf{4 7}$ & $\underline{\mathbf{2 1}}$ & $\mathbf{3 5}$ & $\mathbf{3 4}$ & $\mathbf{3 9}$ & $\underline{\mathbf{3 8}}$ & $\underline{\mathbf{9 1}}$ \\
& T1R3PATCH1 & $\underline{\mathbf{9 1}}$ & $\underline{\mathbf{9 7}}$ & $\mathbf{1 0 3}$ & & & & & & \\
& T1R3PATCH2 & 6 & $\mathbf{9 3}$ & $\mathbf{4 0}$ & $\underline{\mathbf{9 1}}$ & 90 & $\underline{\mathbf{9 7}}$ & $\mathbf{1 0 9}$ & \\
& T1R3PATCH3 & $\mathbf{5 6}$ & $\mathbf{7 1}$ & $\mathbf{5 8}$ & $\mathbf{8 1}$ & & & & \\
& T1R3PATCH4 & 1 & 105 & $\mathbf{1 0 2}$ & $\mathbf{8 3}$ & 9 & 12 & & \\
& T1R3PATCH5 & 48 & 44 & 76 & 74 & & & & \\
\hline
\end{tabular}

predicted as binding residues. In the docking results, these four residues did not appear in the best selected complexes. However, Arg48 appeared in T1R3PATCH5 as shown in Table 1 and Figure 3(a). The residues Tyr65, Val72 and, Phe94 formed hydrophobic interactions in the complexes T1R3PATCH3, T1R3PIPER6 and T1R3PIPER7, respectively, as shown in Figure 3(b)-3(d). Generally, the hydrophobic interactions have significant contribution to the protein-protein interaction (Veselovsky et al. 2002). In the case of neoculin, the hydrophobic interaction provided more stability to neoculin when it bound to the receptors. The current docking results provide a molecular level explanation of the work of Koizumi et al. (2015) because the hydrophobic interaction between neoculin and T1R3 is not effected by the change of $\mathrm{pH}$. This finding explain why neoculin could bind to the ATD of T1R3 regardless of the $\mathrm{pH}$. However, the change of $\mathrm{pH}$ still effecting the hydrogen bonds especially the bonds between the neoculin dimers as mentioned by Ohkubo et al. (2015).

\section{MOLECULAR DYNAMICS SIMULATION}

The MD simulations were performed for 5 complexes, T1R2PIPER4, T1R2PIPER5, T1R3PATCH2, T1R3PIPER4, and T1R3PIPER5 in POPC membrane environment. The hydrogen bond occupancy per residue were calculated between neoculin and T1R2 and T1R3 as shown in Tables 2 and 3, respectively. The overall binding energy using MMPBSA calculation were also calculated between the receptors and neoculin as shown in Table 4 .

The previous results by Nakajima et al. (2011) showed that His11 was an important $\mathrm{pH}$ sensor to activate the neoculin taste modification activity, and it does not bind to the sweet taste receptors. The current docking results supported this finding as mentioned in the docking part. In addition, the results of hydrogen bond occupancy were found to support both the previous experimental results and the docking results, when it showed that His 11 did not involve in the hydrogen bonding throughout the $10 \mathrm{~ns}$ of MD simulation. A previous work by Ohkubo et al. (2015) showed that the interface between His11-Asp91 and the 


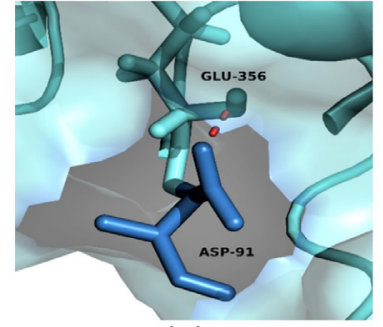

(a)

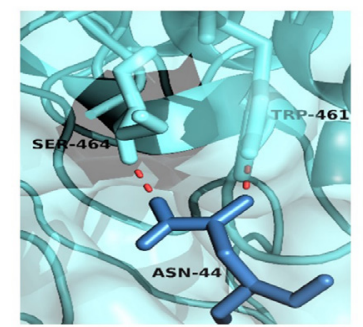

(c)

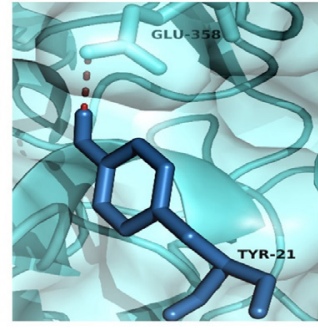

(b)

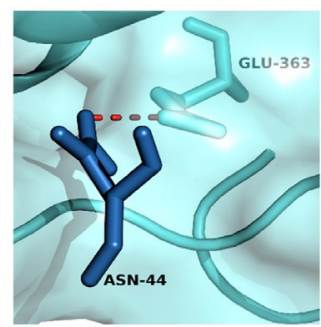

(d)

FIGURE 2. The hydrogen bond interactions between the important residues of neoculin NBS and ATD of T1R3, (a) The hydrogen bond interaction between Asp91 of neoculin and Glu356 of T1R3, (b) The hydrogen bond interaction between Tyr21 of neoculin and Glu358 of T1R3, (c) The hydrogen bond interactions between Asn44 of neoculin and Ser464 and Trp461 of T1R3, and (d) The hydrogen bond interactions between Asn44 of neoculin and Glu36 of T1R3

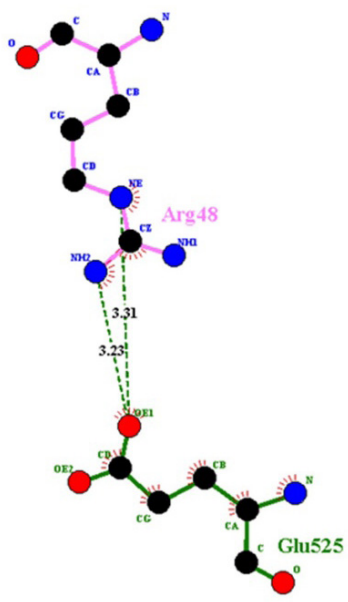

(a)

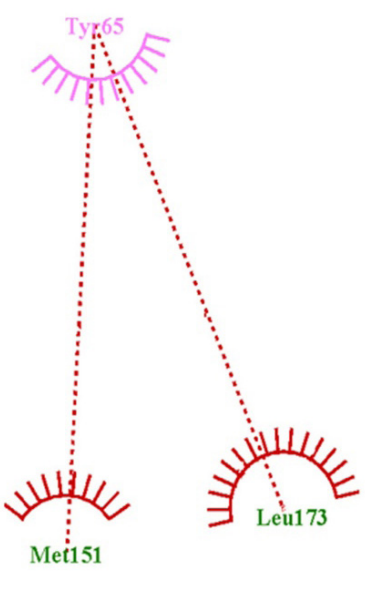

(b)

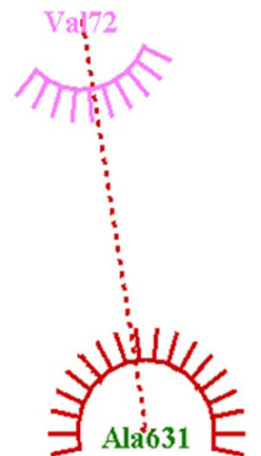

(c)

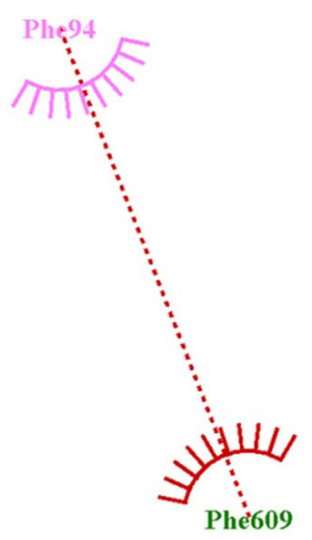

(d)

FIGURE 3. The interactions between the residues Arg48, Tyr65, Val72 and Phe94 of neoculin NBS and ATD of T1R3, (a) The hydrogen bond interaction between Arg48 of neoculin and Glu525 of T1R3, (b) The hydrophobic interaction between Tyr65 of neoculin and Met151 and Leu173 of T1R3, (c) The hydrophobic interaction between Val72 of neoculin and Ala631 of T1R3, and

(d) The hydrophobic interaction between Phe94 of neoculin and Phe609 of T1R3

interface between His14-Tyr21 are crucial as a dimer in neoculin sweetness activity. The current docking results showed how Asp91 and Tyr21 actually bound to the receptor T1R3. The MD results showed the maximum hydrogen bond occupancy of Asp91 which was $82.6 \%$ in T1R3PATCH2. The maximum hydrogen bond occupancy of Tyr 21 were $24.7 \%$ and $17.9 \%$ in both T1R3PATCH2 and T1R3PIPER5, respectively. The same work of Ohkubo et al. (2015) reported that Asn44 was a significant residue at the neoculin NBS for the receptor activation region. The current docking study showed how Asn44 bind to T1R3. The current MD work showed that $15.6 \%$ and 66.7 of the maximum hydrogen bond occupancy of Asn 44 was in T1R3PIPER4 and T1R3PIPER5, respectively. Previous research by Koizumi et al. (2015) showed that the residues Arg48, Tyr65, Val72 and, Phe94 are important to determine the affinity of neoculin with T1R2 and T1R3. The current docking results showed that, out of the four residues, only Arg48 was found to form hydrogen bonds with T1R3. The current MD results showed that Arg48 had 20\% of the 
maximum hydrogen bond occupancy in T1R3PIPER5. The residues Tyr65, Val72 and Phe94 did not have a role in the hydrogen occupancy between neoculin and T1R3, because they form a hydrohobic interaction with the receptor as mentioned in the docking part. Besides the residues mentioned, the current study propose that the residues Lys90, Lys33, Gln35, Gln39, Arg38, Asn36, and Asn30 contribute more to the hydrogen bond occupancy between neoculin and T1R3 in more than one complex. According to a previous review by Veselovsky et al. (2002) more than $47 \%$ of the coil secondary structure regions contribute to the protein-protein interface area. The current study showed that Asp91,Asn44, Arg111, Arg93, Gln89, Gln35, Asp1, Lys90, Asn30, Asn36, Gly3, Ser43, and Gly19 appeared at the coil region. Thus, it can be proposed that these residues might contribute to the interface interactions between neoculin and T1R3. Unexpectedly, the MMPBSA results showed the binding energy between neoculin and T1R2 are lower than the binding energy between neoculin and T1R3, which might due to the nature of the proteinprotein interaction for it is weak and it lasts for a limited duration (Fischer et al. 2015; Kastritis \& Bonvin 2013). However, the strong binding energy between neoculin and T1R2 does not change the fact that neoculin sweet and taste-modifying abilities only activated when it is bind to ATD of T1R3. The MD study provided additional insights to the docking results, by providing more details regarding the interactions between the protein-protein complexes. Throughout the MD simulation, the important residues of neoculin were found to interact only with the ATD of T1R3, which agrees with the previous experimental work of Nakajima et al. (2011) and Ohkubo et al. (2015).

TABLE 2. The hydrogen bond occupancy for T1R2 complexes per residues. The residues in bold representing the neoculin site

\begin{tabular}{lccc}
\hline Complex & Donor & Acceptor & Occupancy (\%) \\
\hline T1R2PIPER4 & Arg111 (H21) & Glu530 (OE1) & 58.7 \\
Arg110 (H11) & Asp480 (OD2) & 60.8 \\
Tyr97 (Hh) & Gln474 (O) & 30.1 \\
Arg93 (H11) & Hsd447 (NE2) & 61.8 \\
Lys90 (Hz1) & Asp712 (OD1) & 50.5 \\
Trp41 (He1) & Leu431 (O) & 33.8 \\
Lys33 (Hz1) & Asp433 (OD2) & 66.4 \\
Gln479 (E21) & Arg111 (OT1) & 32.9 \\
Tyr469 (HH) & Gln89 (NE2) & 22.5 \\
Ter467 (HN) & Ile96 (O) & 29.6 \\
Arg110 (H21) & Asp711 (OD1) & 98.7 \\
Tyr97 (HH) & Asp712 (OD2) & 10.6 \\
Arg93 (H11) & Glu423 (OE2) & 71.0 \\
Trp41 (HE1) & Trp425 (NE1) & 15.7 \\
Arg38 (H21) & Glu422 (OE1) & 28.7 \\
& Arg554 (H21) & Arg111 (OT1) & 69.5 \\
Arg554 (H11) & Asp80 (OD2) & 55.3 \\
\hline
\end{tabular}

TABLE 3. The hydrogen bond occupancy for T1R3 complexes per residues. The residues in bold representing the neoculin site

\begin{tabular}{lccc}
\hline Complex & Donor & Acceptor & Occupancy (\%) \\
\hline T1R3PATCH2 & Arg111 (H21) & Asp124 (OD1) & 53.7 \\
& Arg93 (H11) & Glu363 (O) & 94.0 \\
Lys90 (HZ1) & Glu48 (OE1) & 34.2 \\
Gln89 (E21) & Ser352 (OG) & 16.1 \\
Lys33 (HZ1) & Asp364 (OD2) & 26.1 \\
Arg357 (H11) & Gln35 (OE1) & 31.4 \\
Arg357 (H11) & Tyr21 (OH) & 24.7 \\
Glu356 (HN) & Asp91 (OD2) & 82.6 \\
Ser53 (HG1) & Asp1 (OD1) & 50.7 \\
\hline
\end{tabular}




\begin{tabular}{lccc}
\hline T1R3PIPER4 & Lys90 (HZ1) & Glu363 (OE2) & 24.8 \\
Asn44 (D21) & Gly463 (O) & 15.6 \\
Gln39 (E21) & Ser464 (O) & 26.0 \\
Arg38 (H21) & Asp307 (OD1) & 99.8 \\
Asn36 (D21) & Gly360 (O) & 73.9 \\
Tyr34 (HH) & Leu312 (O) & 10.9 \\
Asn30 (D21) & Ser464 (OG) & 50.1 \\
Trp73 (HE1) & Arg369 (O) & 67.4 \\
Arg48 (H21) & Gln372 (OE1) & 20.0 \\
Arg47 (H21) & Asp374 (OD1) & 49.5 \\
Trp41 (HE1) & Leu361 (O) & 18.5 \\
Gln39 (HN) & Gln379 (OE1) & 19.7 \\
Arg38 (HE) & Asp307 (OD2) & 44.5 \\
Asn36 (D21) & Met310 (O) & 14.5 \\
Gln35 (E21) & Asp307 (OD2) & 20.9 \\
Lys33 (HZ1) & Glu362 (OE1) & 70.7 \\
Asn30 (D21) & Thr377 (OG1) & 37.9 \\
Tyr21 (HH) & Glu358(OE1) & 17.9 \\
Asn386 (D21) & Asn36 (O) & 14.0 \\
Asn380 (D21) & Gly37 (O) & 29.9 \\
Gln379 (E21) & Gln39 (O) & 33.5 \\
Gle376 (HH) & Asn44 (OD1) & 66.7 \\
Met315 (HN) & Ser43 (O) & 29.7 \\
\hline
\end{tabular}

TABLE 4. The MM-PBSA calculation for the binding energy ( $\mathrm{kj} / \mathrm{mol})$ for the first, final and overall 100 frames out of total 5000 frames for each system during the simulation

\begin{tabular}{lccc}
\hline & First 100 frames & Last 100 frames & Overall 100 frames \\
\hline T1R2PIPER4 & -915.436 & -949.065 & -925.801 \\
T1R2PIPER5 & -890.303 & -989.576 & -945.122 \\
T1R3PATCH2 & -338.067 & -314.675 & -347.834 \\
T1R3 PIPER4 & -498.505 & -323.385 & -531.964 \\
T1R3 PIPER5 & -463.033 & -441.202 & -596.806 \\
\hline
\end{tabular}

\section{CONCLUSION}

Since the interactions between neoculin and T1R2 and T1R3 is yet to be understood, this research helped to gain an in depth understanding of the interactions between the sweet protein neoculin and the human sweet taste receptors T1R2 and T1R3. In this study, molecular modeling methods including homology modeling, protein-protein docking, and molecular dynamics simulation were employed. The homology modeling study was performed in order to predict the complete 3D structure of T1R2 and T1R3. To provide more insights into the interaction of neoculin and T1R2 and T1R3, a protein-protein study was conducted in correlation with the major experimental results which reported by previous researchers. The protein-protein docking results were more informative regarding how neoculin interact with the human sweet taste receptors, especially when the docking results were further analyzed by MD simulation study. Therefore, MD simulation study was performed on the best selected complexes from the protein-protein docking study for 10 ns. The current study presented how Tyr21, Asp9, Asn44, and Arg48 of neoculin bind specifically to the ATD of T1R3, and the hydrogen occupancy of these residues. Furthermore, the recent docking study had provided conclusive evidence that His11 did not bind to the ATD of T1R3 at all. In addition, this research showed that neoculin form hydrophobic interactions with the ATD of T1R3, specifically by the residues Tyr65, Val72, and Phe94. Which explained why neoculin binds to the human sweet taste receptors regardless of the $\mathrm{pH}$. 


\section{ACKNOWLEDGEMENTS}

The authors acknowledge the financial support provided by Universiti Teknologi Malaysia (UTM) RU grant (Vot number: 19h73).

\section{REFERENCES}

Altschul, S.F., Madden, T.L., Schaffer, A.A., Zhang, J., Zhang, Z., Miller, W. \& Lipman, D.J. 1997. Gapped BLAST and PSI-BLAST: A new generation of protein database search programs. Nucleic Acids Res. 25(17): 3389-3402.

Assadi-Porter, F.M., Maillet, E.L., Radek, J.T., Quijada, J., Markley, J.L. \& Max, M. 2010. Key amino acid residues involved in multi-point binding interactions between brazzein, a sweet protein, and the T1R2,T1R3 human sweet receptor. Journal of Molecular Biology 398(4): 584-599.

Binkowski, T.A., Naghibzadeh, S. \& Liang, J. 2003. CASTp: Computed atlas of surface topography of proteins. Nucleic Acids Res. 31(13): 3352-3355.

Castleman, P.N., Sears, C., Cole, J.A., Baker, D.L. \& Parrill, A.L. 2018. GPCR homology model template selection benchmarking: Global versus local similarity measures. Journal of Molecular Graphics and Modelling 86: 235-246.

Cheron, J.B., Golebiowski, J., Antonczak, S. \& Fiorucci, S. 2017. The anatomy of mammalian sweet taste receptors. Proteins 85(2): 332-341.

Comeau, S.R., Gatchell, D.W., Vajda, S. \& Camacho, C.J. 2004. ClusPro: A fully automated algorithm for protein-protein docking. Nucleic Acids Research 32(2): W96-W99.

Cuff, J.A., Clamp, M.E., Siddiqui, A.S., Finlay, M. \& Barton, G.J. 1998. JPred: A consensus secondary structure prediction server. Bioinformatics 14(10): 892-893.

Cui, M., Jiang, P.H., Maillet, E., Max, M., Margolskee, R.F. \& Roman Osman. 2006. The heterodimeric sweet taste receptor has multiple potential ligand binding sites. Current Pharmaceutical Design 12(35): 4591-4600.

Dias, R. \& de Azevedo Jr., W.F. 2008. Molecular docking algorithms. Current Drug Targets 9(12): 1040-1047.

Eswar, N., Webb, B., Marti-Renom, M.A., Madhusudhan, M.S., Eramian, D., Shen, M-Y., Pieper, U. \& Sali, A. 2007. Comparative protein structure modeling using MODELLER. Current Protocols in Protein Science 50(1): 2.9.1-2.9.31.

Fischer, G., Rossmann, M. \& Hyvönen, M. 2015. Alternative modulation of protein-protein interactions by small molecules. Current Opinion in Biotechnology 35: 78-85.

Ho, B.K. \& Brasseur, R. 2005. The Ramachandran plots of glycine and pre-proline. BMC Structural Biology 5: 14.

Huang, S-Y. 2015. Exploring the potential of global proteinprotein docking: An overview and critical assessment of current programs for automatic ab initio docking. Drug Discovery Today 20(8): 969-977.

Kastritis, P.L. \& Bonvin, A.M.J.J. 2013. The binding affinity of macromolecular interactions: Daring to ask why proteins interact. Journal of The Royal Society Interface 10(79): 20120835.

Kim, S.K., Chen, Y., Abrol, R., Goddard, W.A. \& Guthrie, B. 2017. Activation mechanism of the $G$ protein-coupled sweet receptor heterodimer with sweeteners and allosteric agonists. Proc. Natl. Acad. Sci. USA 114(10): 2568-2573.

Koizumi, T., Terada, T., Nakajima, K-I., Kojima, M., Koshiba, S., Matsumura, Y., Kaneda, K., Asakura, T., ShimizuIbuka, A., Abe, K. \& Misaka, T. 2015. Identification of key neoculin residues responsible for the binding and activation of the sweet taste receptor. Scientific Reports 5: 12947.

Koizumi, A., Nakajima, K., Asakura, T., Morita, Y., Ito, K., Shmizu-Ibuka, A., Misaka, T. \& Abe, K. 2007. Tastemodifying sweet protein, neoculin, is received at human T1R3 amino terminal domain. Biochemical and Biophysical Research Communications 358(2): 585-589.

Kozakov, D., Hall, D.R., Xia, B., Porter, K.A., Padhorny, D., Yueh, C., Beglov, D. \& Vajda, S. 2017. The ClusPro web server for protein-protein docking. Nat. Protoc. 12(2): 255278.

Kumari, R., Kumar, R., Open Source Drug Discovery Consortium. \& Lynn, A. 2014. g mmpbsa A GROMACS tool for high-throughput MM-PBSA calculations. Journal of Chemical Information and Modeling 54(7): 1951-1962.

Kurimoto, E., Suzuki, M., Amemiya, E., Yamaguchi, Y., Nirasawa, S., Shimba, N., Xu, N., Kashiwagi, T., Kawai, M., Suzuki, E. \& Kato, K. 2007. Curculin exhibits sweet-tasting and taste-modifying activities through its distinct molecular surfaces. Journal of Biological Chemistry 282(46): $33252-$ 33256 .

Lee, J., Cheng, Xi., Swails, J.M., Yeom, M.S., Eastman, P.K., Lemkul, J.A., Wei, S., Buckner, J., Jeong, J.C., Qi, Y.F., Jo, S.H., Pande, V.S., Case, D.A., Brooks, III, C.L., MacKerell Jr., A.D., Klauda, J.B. \& Im, W.P. 2015. CHARMMGUI input generator for NAMD, GROMACS, AMBER, OpenMM, and CHARMM/OpenMM simulations using the CHARMM36 additive force field. Journal of Chemical Theory and Computation 12(1): 405-413.

Lomize, M.A., Pogozheva, I.D., Joo, H., Mosberg, H.I. \& Lomize, A.L. 2012. OPM database and PPM web server: Resources for positioning of proteins in membranes. Nucleic Acids Research 40(D1): D370-D376.

Loo, J.S.E., Emtage, A.L., Ng, K.W., Yong, A.S.J. \& Doughty, S.W. 2018. Assessing GPCR homology models constructed from templates of various transmembrane sequence identities: Binding mode prediction and docking enrichment. Journal of Molecular Graphics and Modelling 80: 38-47.

Maillet, E.L., Cui, M., Jiang, P., Mezei, M., Hecht, E., Quijada, J., Margolskee, R.F., Osman, R. \& Max, M. 2015. Characterization of the binding site of aspartame in the human sweet taste receptor. Chem. Senses 40(8): 577-586.

Masuda, K., Koizumi, A., Nakajima, K., Tanaka, T., Abe, K., Misaka, T. \& Ishiguro, M. 2012. Characterization of the modes of binding between human sweet taste receptor and low-molecular-weight sweet compounds. PLoS ONE 7(4): e35380.

Masuda, T. \& Kitabatake, N. 2006. Developments in biotechnological production of sweet proteins. Journal of Bioscience and Bioengineering 102(5): 375-389.

Mukherjee, S. \& Zhang, Y. 2011. Protein-protein complex structure predictions by multimeric threading and template recombination. Structure 19(7): 955-966.

Nakajima, K-I., Yokoyama, K., Koizumi, T., Koizumi, A., Asakura, T., Terada, T., Masuda, K., Ito, K., ShimizuIbuka, A., Misaka, T. \& Abe, K. 2011. Identification and modulation of the key amino acid residue responsible for the $\mathrm{pH}$ sensitivity of neoculin, a taste-modifying protein. PLOS ONE 6(4): e19448.

Nakajima, K., Morita, Y., Koizumi, A., Asakura, T., Terada, T., Ito, K., Shimizu-Ibuka, A., Maruyama, J., Kitamoto, K., Misaka, T. \& Abe, K. 2008. Acid-induced sweetness 
of neoculin is ascribed to its $\mathrm{pH}$-dependent agonisticantagonistic interaction with human sweet taste receptor. FASEB J. 22(7): 2323-2330.

Ohkubo, T., Tamiya, M., Abe, K. \& Ishiguro, M. 2015. Structural basis of $\mathrm{pH}$ dependence of neoculin, a sweet taste-modifying protein. PloS ONE 10(5): e0126921.

Ohta, K., Masuda, T., Tani, F. \& Kitabatake, N. 2011. Introduction of a negative charge at Arg82 in thaumatin abolished responses to human T1R2-T1R3 sweet receptors. Biochemical and Biophysical Research Communications 413(1): 41-45.

Oshiro, C., Bradley, E.K., Eksterowicz, J., Evensen, E., Lamb, M.L., Lanctot, J.K., Putta, S., Stanton, R. \& Grootenhuis, P.D.J. 2004. Performance of 3D-Database molecular docking studies into homology models. Journal of Medicinal Chemistry 47(3): 764-767.

Schneidman-Duhovny, D., Inbar, Y., Nussinov, R. \& Wolfson, H.J. 2005. PatchDock and SymmDock: Servers for rigid and symmetric docking. Nucleic Acids Research 33(2): W363-W367.

Shrivastav, A. \& Srivastava, S. 2013. Human sweet taste receptor: Complete structure prediction and evaluation. International Journal of Chemical and Analytical Science 4(1): 24-32.

Sievers, F., Wilm, A., Dineen, D., Gibson, T.J., Karplus, K., Weizhong, L., Lopez, R., McWilliam, H., Remmert, M. \& Söding, J. 2011. Fast, scalable generation of high-quality protein multiple sequence alignments using Clustal Omega. Molecular Systems Biology 7(1): 539.

Veselovsky, A.V., Ivanov, Y.D., Ivanov, A.S., Archakov, A.I., Lewi, P. \& Janssen, P. 2002. Protein-protein interactions: Mechanisms and modification by drugs. Journal of Molecular Recognition 15(6): 405-422.

Wallace, A.C., Laskowski, R.A. \& Thornton, J.M. 1995. LIGPLOT: A program to generate schematic diagrams of protein-ligand interactions. Protein Engineering 8(2): 127 134.
Yamashita, H., Theerasilp, S., Aiuchi, T., Nakaya, K., Nakamura, Y. \& Kurihara. 1990. Purification and complete amino acid sequence of a new type of sweet protein with tastemodifying activity, curculin. The Journal of Biochemical Chemistry 265(6): 15770-15775.

Yang, J., Roy, A. \& Zhang, Y. 2013. Protein-ligand binding site recognition using complementary binding-specific substructure comparison and sequence profile alignment. Bioinformatics 29(20): 2588-2595.

Yarnitzky, T., Levit, A. \& Niv, M.Y. 2010. Homology modeling of G-protein-coupled receptors with X-ray structures on the rise. Curr. Opin. Drug Discov. Devel. 13(3): 317-325.

Ragheed Hussam Yousif, Kamyar Shameli \& Nurul Bahiyah Ahmad Khairudin*

Department of Environment and Green Technology Malaysia-Japan International Institute of Technology

Universiti Teknologi Malaysia

Jalan Sultan Yahya Petra

54100 Kuala Lumpur, Federal Territory

Malaysia

Habibah A. Wahab

School of Pharmaceutical Sciences

Universiti Sains Malaysia

11800 Universiti Sains Malaysia, Pulau Pinang

Malaysia

*Corresponding author; email: r-bahiah@utm.my

Received: 24 May 2019

Accepted: 5 December 2019 
